\title{
Erratum to: Rural environment and risk factors of amyotrophic lateral sclerosis: a case-control study
}

\author{
Alain Furby $\cdot$ Katell Beauvais • Ivan Kolev • \\ Jean-Gérard Rivain • Véronique Sébille
}

Published online: 17 April 2010

(C) Springer-Verlag 2010

\section{Erratum to: J Neurol}

\section{DOI 10.1007/s00415-009-5419-5}

Unfortunately, in the second paragraph of the discussion, there is a typing error in references. The text should read "...in contrast with others $[11,19,26,31,33,34]$ " and not “...in contrast with others $[1,7,8,10,11,17,19,21,22,26$, 27, 30-34]".

The online version of the original article can be found under doi:10.1007/s00415-009-5419-5.

A. Furby $(\bowtie) \cdot$ K. Beauvais $\cdot$ I. Kolev

Unité de Neurophysiologie Clinique, Hôpital Yves Le Foll, 22027 Saint-Brieuc, France

e-mail: alain.furby@ch-stbrieuc.fr

J.-G. Rivain · V. Sébille

Biostatistique, Recherche Clinique et Mesures Subjectives en Santé, Faculté de Pharmacie, EA 4275, Université de Nantes, Nantes, France 